UDC 81'373.45

DOI: $10.17223 / 24109266 / 11 / 4$

\title{
FROM SIBERIA WITH LOVE: IMAGES OF SIBERIA IN CONTEMPORARY AMERICAN NOVELS
}

\author{
N.E. Nikonova, D.R. Gorbyleva \\ This research is supported by the Russian Foundation for Basic Research \\ and Tomsk Oblast Administration grant (project № 17-14-70006).
}

\begin{abstract}
Here is analyzed and attributed the concept of Siberia and its connection with zoomorphic code within the materials of contemporary American literature. The purpose of this research is to investigate how this connection is implemented in the image of Siberia and how it is related to the imaginative geographies of the texts.
\end{abstract}

Keywords: Siberia, imaginative geographies, zoomorphisms, comparative literature.

\section{Introduction}

Bright student time during the bachelor's program flies imperceptibly. You will not believe when four years have passed and you come out with a diploma and hopes for a bright future, confident in yourself and in your knowledge. A student can rock mountains!

Recently, I have graduated from Tomsk State University - it was almost a year and a half ago. That time I thought that I had been taught everything and the only thing I should do is to go and show off. The next step was applying for the Master's and I have done it easily. Though, the very first day saw my failure on the course "Translation of an artistic text" when I got lost in literary terms, although philology is my major and I am proud of my knowledge. Things happen. Anyway, it was not the main reason for remembering my first year of Master's. The real amazement came when I understood that I knew nothing about the city, region and culture I live in. The question "What is Siberia?" seems to be utterly simple. Several months ago I might answered: just a region in Central Russia. However, having studied in TSU Master's for a year, I learnt, heard and was astonished by a lot of remarkable things. Get ready to be amazed.

\section{Siberia in contemporary English novels}

To begin with, I was proposed to take up Siberian representations in English-written novels by my research supervisor Natalia Nikonova, $\mathrm{PhD}$ in Philology. Having spent several weeks in libraries, I formed a list of contemporary text set in my region. The first thing that amazed me was the 
number of novels: 26 books about Siberia have been published since the middle of 20th century. The size of the region (1.5 Brazil, 4 Indias, 19 Frances, moreover, it is $56 \%$ of all territory of Russia) is appealing for various plots, the novels are published approximately once in five years. Among the authors one can find both popular persons as James Meek and his widely and unfavorably known novel People's Act of Love and, at the same time, artists who devote their life to collect information about Siberia. Though, there have been published only several books that were not interesting for mass media, these novels contributed to my research. Among them is historical-anthropological novel The Reindeer People: Living with Animals and Spirits in Siberia (2006) by Piers Vitebsky. Analyzing these sources, I noticed a tendency to represent Siberia through zoomorphic images due to the emphasized role of fauna in the plots.

\section{The Bear and the Dragon as world-wide zoomorphic symbols}

The topic has been chosen and the recourses were worked through. My research began from the analysis of bestsellers, including a technothriller The Bear and The Dragon (2001) by an American well-known author, Tom Clancy. In terms of zoomorphic insertions, this novel is utterly symbolical and stereotypical: the bear stands for Russia, the dragon represents China, and the USA is shown as a mediator without need for any animal mascot - the image structure is as simple as ABC. However, at the same time, I have never thought that Siberia could be viewed by other cultures as a profitable colony. T. Clancy depicts an abundant place full of natural resources and ancient treasures, yet it is inhabited by tribes of reindeer herders who do not appreciate these riches. Indeed, my region has every kind of marvel! Look at its vast space: the taiga stretches for thousands of kilometers and fields go beyond the horizon. Nature has endowed my region with endless resources - ore, oil, wood. The territory of Siberia is sparsely populated (approximately 39.13 million) and natives make up $4.06 \%$ of this number, but the tribes of reindeer herders are already up to date and one can hardly meet a person without an account in Instagram, even if he or she lives with deer behind the polar circle. The image of Siberia in Clancy's novel acquires oriental features acting as a place where the American dream becomes a reality due to the resource riches of the region. However, in the figurative system of the novel, zoomorphism is intended to reveal not only narrowmindedness of local residents, but also the underdevelopment of those who represent national interests in hunting for Siberian riches: Americans, Russians, and Chinese. This idea of colonial dream can be traced in contemporary works as well as in the culture of English-speaking nations. 


\section{Siberia as a place of exile}

Looking at the same picture of Tomsk landscapes during the course Landscapes / Mindscapes (the University of Mannheim, Germany where I had taken a 3-month academic internship), the listeners perceived the taiga forests in absolutely different ways: I saw this place as a temple of nature, wild, untouched and charmingly native; my American fellow-students came up with an idea of a cosmopolitan city and country's economic expansion on the ground of this promising area. These differences in the views and axiology of the representatives who come from different linguistic societies allow me for the first time to look differently at our culture and understand others better.

The next work rendered with remarkable specificity and attention to Siberia was an epistolary novel Between Shades of Gray (2011) by Ruta Sepetys, an American writer of Lithuanian origin. This novel conveys a story of a Lithuanian girl, Lina, whose family was sentenced to exile to a military camp in the Altai Territory in the 1930s. The book is utterly impressive. It describes the plight of Lithuanians who were forced to adapt to a foreign culture, eternal cold and life 'as animals'. However, there were moments which I simply could not believe in: how did it happen that among all the Siberian soldiers there was not a soul who would treat prisoners with understanding and compassion? Almost all of them were young, educated people, who joined the army against their will, so, in a way, they were in chains as well. R. Sepetys makes the speech of the military staff full of, zoomorphic metaphors, with 'pig' dominating in this structure. As far as the connotations of this animal image in European culture is connected with such features as unscrupulousness, stupidity, dishonesty, one can come to the conclusion that the zoonym is used to characterize an 'enemy' and, simultaneously, shows inequality between the exiled prisoners and Siberian guards. Thus, in the novel all the zoonyms tend to reveal hostility, unfriendliness, misanthropy, the absence of humanity in exile applying in the same way to a child. Throughout the book, I hoped to see at least one person in the Altai Territory who would give a hand to the protagonists, yet there was not a ray of hope Between Shades of Gray. Having finished the book, I asked myself: what image of a Siberian will it form in the mind of an English-speaking reader? A ruthless and merciless robot-soldier who is unaware of the value of human life and unable to empathize with another person? It might be so. However, one story is not the whole truth, it is just a piece in a huge jigsaw picture, and therefore we need to turn to another work to see the difference.

\section{Decembrists and animals}

Princess of Siberia (1983), a biographical novel by an American Catherine Sutherland was the third book in my list that was set in Siberia. 
It progresses from remembrance of childhood (1805) of Princess Maria Volkonskaya, a Decembrist's wife, to her death (1863). She was an incredible, brave woman who was not afraid to act against the tsar's will and, at the age of 21, followed her husband to the 'wildest' region of the Russian Empire. I happened to be reading this novel while studying in Germany, though the feeling of home did not leave me for a minute. C. Sutherland has done vast research on the Decembrists' lives: she traveled the same way as Maria Volkonskaya, visited prisons and prisoners' houses, collected information from letters and finally published a book in which the image of the region obtains absolutely different features. Here one could find an opposition of two worlds: on the one hand, a prosperous European Russia, where French maids and summer trips to Italy were common among members of high society and, on the other, the nascent Siberian culture, pristine and historically orientated to the east. The most captivating part starts from the Decembrist's rebellion; further, the author describes a phenomenon of adaptation to new conditions in the settlements by the best minds of that generation, some of whom did not know the Russian language. In the novel different zoonyms perform are used for the household description and show the importance of animals for Siberian folks: pets are more like true friends; cattle are a treasure that could feed a family of several people. In my mind, the given concept of "returning to Siberia for a reversion to nature" can be considered as the most accurate interpretation of the image of my region.

\section{Conclusion}

To sum it up, I would claim that while researching foreign literature works, one can understand their own culture better and have an opportunity to be 'an alien', 'another' to observe the most incredible and shocking things from abroad. Initially, the analysis of Siberian representations and zoomorphic categories seemed to me an impossible task due to my misunderstanding of this study importance. With its unique history and cultural heritage, Siberia has great potential, yet for the rest of the world it remains a blank spot on the mental map. These two years allowed me to concentrate on the research and to see the importance of studying my culture through the prism of another national picture of the world. I believe that the comparative studies and imagology are the future of science, since a view from the outside is essential to see a holistic image in all its diversity.

\section{References}

1. Clancy, T.: The Bear and the Dragon. N. Y.: Berkley Books (2001)

2. Meek, J.: People's Act of Love. N. Y.: Canongate (2005)

3. Sepetys, R.: Between Shades of Gray. N. Y.: Puffin (2011) 
4. Sutherland, C.: Princess of Siberia: the story of Maria Volkonsky and the Decembrist Exiles. N. Y.: Farrar (1984)

5. Vitebsky, P.: The Reindeer People: Living with Animals and Spirits in Siberia. N.Y.: Houghton Mifflin Company (2005)

\section{Information about the authors:}

Gorbyleva D.R. - Department of Romano-Germanic Philology, Faculty of Philology, Tomsk State University (Tomsk, Russia). E-mail: visitasion1994@gmail.com

Nikonova N.E. - D. Sc. (Philology), Head of Department of Romano-Germanic Philology, Faculty of Philology, Tomsk State University (Tomsk, Russia). E-mail: nikonat2002@yandex.ru 